\title{
Available and emerging technologies for assessing intraoperative tissue perfusion during complex ventral hernia repair procedures
}

This article was published in the following Dove Press journal:

Open Access Surgery

18 December 2013

Number of times this article has been viewed

\section{Stephen J Ferzoco}

Dedham Medical Associates, Dedham, MA, USA
Correspondence: Stephen J Ferzoco Dedham Medical Associates, One Lyons Street, Dedham, MA, USA 02026

$\mathrm{Tel}+\mathrm{I} 78 \mid 329$ |400

Fax +I 78I 3296637

Email sferzoco@gmail.com

\begin{abstract}
Abdominal wall reconstructions, and complex ventral hernia repairs in particular, pose significant challenges to surgeons and are associated with serious postoperative wound healing complications often related to poor tissue perfusion. Maintenance of adequate perfusion of central adipocutaneous tissue is critical for minimizing risk of wound-related complications following herniorrhaphy; however, accurate tissue perfusion assessment can be challenging in this setting. Technologies such as thermography and laser Doppler flowmetry are not widely used in clinical settings to assess tissue perfusion, and most surgeons currently rely upon subjective assessments of tissue viability to guide intraoperative decisions regarding reconstruction. New technological developments, including spectroscopic imaging and indocyanine green-based near-infrared laser fluorescence, permit quantitative, real-time, intraoperative visualization of tissue perfusion and have demonstrated sensitivity and accuracy in a variety of reconstructive settings. Evidence suggests these technologies can be used to optimize perfusion at the time of operation and prevent perfusion-related complications such as flap necrosis. Future studies and physician reports describing these perfusion assessment technologies in complex ventral hernia repair will supply important information regarding their utility in patients undergoing this procedure.
\end{abstract}

Keywords: indocyanine green imaging, spectroscopic imaging, hernia repair, intraoperative tissue perfusion, complications, tissue ischemia

\section{Introduction}

Complex abdominal wall defects requiring surgical reconstruction may result from trauma, recurrence after prior repairs, tumor ablation/resection, or congenital defects. ${ }^{1,2}$ Incisional hernias, including ventral abdominal hernias, are among the most common type of abdominal wall defect, with reported incidences ranging from $4 \%-20 \%$ of abdominal wall reconstruction cases. ${ }^{1,3-6}$ There are approximately 250,000 procedures of this type performed each year in the United States. ${ }^{7}$

Repair of complex ventral abdominal hernias poses technical challenges to both plastic and reconstructive surgeons and general surgeons. ${ }^{1,8,9}$ Providing adequate protection and functional support for abdominal organs can be difficult, and defects that are too large to be repaired via primary closure are commonly encountered. ${ }^{9,10}$ Surgeons must consider how to use existing muscle and fascia to reconstruct the abdominal wall, preserve the integrity of overlying soft tissues, and achieve wound closure with an optimal level of tension while maintaining adequate blood supply throughout the surgical procedure. ${ }^{11}$ Management of such patients often requires a multidisciplinary team and careful preoperative planning and may necessitate a multistaged reconstructive approach., ${ }^{9,10}$ 
Complex ventral herniorrhaphy continues to be associated with significant postsurgical morbidity; complications such as wound dehiscence, skin or flap necrosis, hernia recurrence, and abdominal compartment syndrome may lead to the need for unplanned revisional surgeries. ${ }^{8,9}$

The purpose of this review is to address the importance of accurately assessing intraoperative tissue perfusion in patients undergoing ventral abdominal herniorrhaphy and to provide an overview of emerging technologies for perfusion assessment in this setting.

\section{Approaches to ventral abdominal herniorrhaphy}

There has been a general evolution over the last two decades regarding the anatomic approach to repair of ventral hernias. In contrast to earlier perspectives, the anatomy is now viewed less as a single bulk unit and more as two separate units: adipocutaneous and myofascial. This view gained acceptance largely as a result of the components-separation technique first described in 1990 by Ramirez et al. ${ }^{12}$ Preserving perfusion in ventral herniorrhaphy is partially dependent upon the level of tension applied during closure. It is desirable to achieve adequate myofascial exposure in order to allow wound closure with an optimal level of tension while preserving perfusion to adipocutaneous tissue. Adequate exposure of myofascial tissue facilitates tension-free closure, although damage caused during manipulation of the myofascia may compromise perfusion to adipocutaneous tissue. Too much tension, by contrast, may lead to dehiscence.

Despite awareness on the part of the surgeon regarding these issues, ${ }^{13,14}$ perfusion to the central abdominal adipocutaneous tissue is often compromised. In some cases, this issue may be compounded by limitations to blood flow caused by scarring from previous surgeries. The consequence of poor perfusion to this critical area often is delayed wound breakdown caused by necrosis. Ideally, the surgeon would prevent such necrosis by resecting all nonviable, hypoperfused tissue while leaving as much adequately perfused tissue as possible to minimize tension on the closure. Intraoperative decision making based on tissue perfusion is hindered by the lack of adequate, objective perfusion assessment tools. Without intraoperative quantification of perfusion, the surgeon typically closes the wound (unless there is obvious compromise warranting debridement), allows the tissue to demarcate postoperatively, and then performs necessary debridement and/or wound care. The need for postoperative debridement lengthens and complicates the recovery process and increases the risk for secondary surgery. Treatment of these complications adds unnecessary costs to the healthcare system. In this era of healthcare reform, additional costs and compromised outcomes are under scrutiny.

Various surgical approaches can be employed to address the challenges of achieving closure with optimal tension and preservation of tissue perfusion. For ventral herniorrhaphy, these include open and laparoscopic techniques, ${ }^{13,15-17}$ suture/ primary closure, ${ }^{13,14}$ components separation, ${ }^{9,11-13,18-22}$ and use of biologic matrices and synthetic meshes. ${ }^{7,13,14,23}$

\section{Burden of postsurgical complications associated with ventral herniorrhaphy}

Reported complication rates after complex ventral herniorrhaphy are as high as 54\%. ${ }^{11,24-27}$ Wound-related complications such as infection, seroma, skin necrosis, and dehiscence may result in additional surgical procedures, ${ }^{9,26}$ longer inpatients stays, and additional outpatient care. A recent retrospective study of high-risk patients undergoing ventral hernia repair showed that the average cost of complications for patients with a potentially contaminated surgical site $(\mathrm{n}=529)$ ranged from $\sim \$ 4,350$ for those who received a biologic matrix to $\sim \$ 17,300$ for those whose hernias were repaired using synthetic mesh. ${ }^{27}$ Complication costs for those who had primary repair alone averaged $\sim \$ 11,500$. For those with an infected surgical site $(\mathrm{n}=182)$, average complication costs were $\sim \$ 9,000$ at 18 months (all of these hernias were repaired using either a biologic matrix or primary repair alone). These types of wound-healing complications may arise from biomechanical problems, perfusion impairment, or contamination; more commonly, they are linked to an overlapping combination of these factors.

Wound infection rates reported in studies of patients treated with mesh products have ranged from $2 \%-26 \%{ }^{27-35}$ and from $4 \%-20 \%$ in studies of mixed patient populations receiving suture or mesh repair, $, 96,36-40$ with reported per-patient infection-related costs of up to $\sim \$ 4,700 .{ }^{27}$ Wound infection significantly increases the risk of hernia recurrence, ${ }^{28,41}$ and in some cases it may necessitate reoperation for removal of implanted material. The reported incidence of explantation in the literature ranges from $1.5 \%-44.0 \% .^{26,30,35,42,43}$

Seroma predisposes the patient to surgical-site infection and in some cases may lead to major complications, including the need for removal of mesh and revisional surgery. ${ }^{9,44}$ To prevent seroma formation, closed drains are often placed around the implanted material. ${ }^{45}$ Despite preemptive measures, the reported incidence of seroma in retrospective and prospective studies ranges from 2\%-78\%, ${ }^{9,19,32-35,39,40,44,46,47}$ 
with reported seroma-related complication costs averaging up to $\$ 260$ per patient. ${ }^{27}$

The rates of skin necrosis and wound dehiscence following ventral herniorrhaphy vary widely across published reports. A meta-analysis of 14 retrospective studies comprising 460 patients undergoing herniorrhaphy found a skin necrosis rate of $1.5 \% .{ }^{9}$ More recently published single-center case series of complex herniorrhaphy show considerably higher skin necrosis rates, ranging from $19.8 \%-31.6 \%{ }^{48-50}$ Comorbid conditions such as atherosclerosis and chronic nicotine and alcohol use may compromise tissue perfusion and complicate wound healing. ${ }^{10}$

Reported rates of wound dehiscence following ventral herniorrhaphy have ranged from $<1 \%-21 \%,{ }^{32,51}$ with causes of this variation most likely related to patient risk factors, procedural complexity, and surgical approach.

\section{Maintaining tissue perfusion during and after reconstructive surgery}

Optimal tissue perfusion/viability is paramount to reconstructive surgery; meticulous debridement of all infected or necrotic tissue is critical to successful outcomes. ${ }^{52-54}$ Data from patients undergoing several types of reconstructive surgery (including ventral hernia repair) have shown that tissue ischemia is associated with complications that include infection, delayed wound healing, prosthesis extrusion/ explantation, recurrence, and flap necrosis. ${ }^{9,55,56}$ Infections that occur in ischemic tissue lead to worse outcomes than infections that occur in well-perfused tissue. ${ }^{56,57}$

Several devices and technologies have been studied for assessment of tissue perfusion (Table 1) ${ }^{53,58-67}$ Due to technical and practical limitations, however, most existing technologies are rarely used in everyday clinical practice. ${ }^{53,59-63,68-70}$ Sodium fluorescein, an older technology that has been more commonly applied than other methods of perfusion assessment, is an injectable contrast dye that illuminates with ultraviolet light in perfused tissue areas. ${ }^{63,64}$ Although it is considered generally safe, rare incidences $(<1 \%)$ of severe complications have included bronchospasm, respiratory arrest, and stroke. ${ }^{64,65}$ Fluorescein has a long half-life, which limits the ability to reinject during surgery, and the dye may leak from capillaries, which may yield fluorescence even in poorly perfused tissue. ${ }^{63}$ The usefulness of fluorescein in patients with impaired renal function is limited ${ }^{71}$ moreover, its use requires darkness and reveals perfusion only in superficial dermis. ${ }^{66,67,71}$

Due to the limitations of these older methods of assessment, the surgeon's clinical observation and judgment regarding tissue characteristics such as temperature, color, capillary refill, bleeding to pinprick, and tissue turgor are used as the standard of care for assessment of tissue-flap perfusion in reconstructive procedures. Clinical judgment,

Table I Older technologies studied for perfusion assessment

\begin{tabular}{|c|c|c|}
\hline & Mechanism & Limitations \\
\hline Thermography ${ }^{58,59}$ & $\begin{array}{l}\text { Measures tissue surface area } \\
\text { as a surrogate for perfusion }\end{array}$ & $\begin{array}{l}\text { Shallow depth of measurement } \\
\text { Susceptible to inaccuracies caused by temperature } \\
\text { variation }\end{array}$ \\
\hline Photoplethysmography ${ }^{53}$ & $\begin{array}{l}\text { Measures hemoglobin concentrations } \\
\text { in dermal capillary red blood cells }\end{array}$ & $\begin{array}{l}\text { Susceptible to inaccuracies caused by excessive motion } \\
\text { of the probe } \\
\text { Time delays from scanning to interpretation }\end{array}$ \\
\hline LD flowmetry ${ }^{53,59}$ & Measures flow of red blood cells & $\begin{array}{l}\text { Susceptible to inaccuracies caused by probe } \\
\text { movement, environmental changes, and electrical noise } \\
\text { Does not visualize microcirculation }\end{array}$ \\
\hline LD scan imaging 59,60 & $\begin{array}{l}\text { Measures flow of red blood cells } \\
\text { without touching tissue }\end{array}$ & $\begin{array}{l}\text { Susceptible to interference by visible light } \\
\text { Time delays from scanning to interpretation }\end{array}$ \\
\hline Transcutaneous oximetry ${ }^{61-63}$ & Measures partial $\mathrm{PO}_{2}$ in tissue & $\begin{array}{l}\text { Provides only estimated } \mathrm{PO}_{2} \text { values } \\
\text { Lacks visual data output } \\
\text { Susceptible to inaccuracies caused by probe } \\
\text { movement, environmental interference, and existence } \\
\text { of patient comorbidities }\end{array}$ \\
\hline Sodium fluorescein dye ${ }^{64-67}$ & $\begin{array}{l}\text { Fluorescent contrast dye illuminates } \\
\text { with ultraviolet light (higher intensity } \\
\text { in well-perfused tissue) }\end{array}$ & $\begin{array}{l}\text { Potential for adverse events } \\
\text { Long half-life limits ability to reinject during surgery } \\
\text { Low molecular weight allows diffusion from capillary } \\
\text { beds into interstitium } \\
\text { Requires darkness for use } \\
\text { Limited depth of measurement }\end{array}$ \\
\hline
\end{tabular}

Abbreviations: LD, laser Doppler; $\mathrm{PO}_{2}$, pressure of oxygen. 
however, is often inconsistent, as it is highly subjective and depends upon the experience and abilities of the individual surgeon. ${ }^{53,56,72}$ There is an unmet need for reliable, accurate, and precise methods to objectively assess tissue perfusion intraoperatively during incisional herniorrhaphy, as many of the complications that occur following this procedure are due to inaccurate assessment of tissue perfusion at the time of repair.

\section{Novel approaches to tissue perfusion assessment Near-infrared spectroscopy}

Advances in pulse oximetry technology have led to the development of a noninvasive bedside near-infrared spectroscopy (NIRS) tissue-perfusion monitoring device that yields real-time, continuous measurement of tissue oxygenation. ${ }^{73}$ The NIRS device probe emits light in wavelengths longer than visible light and in a narrower spectrum, penetrating to a depth of a few centimeters and measuring both oxyhemoglobin and deoxyhemoglobin. ${ }^{73,74}$ Few published reports are available regarding application of NIRS technology for intraoperative tissue perfusion. However, successful use of NIRS for intraoperative monitoring of tissue oxygen saturation has been demonstrated in patients undergoing abdominal aortic aneurysm surgery, ${ }^{75}$ cardiac surgery, ${ }^{76}$ and colorectal surgery. ${ }^{77}$ According to one published report, NIRS yielded accurate and reliable intraoperative perfusion assessments when used repeatedly during abdominal wall reconstruction and other types of reconstructive surgeries. ${ }^{74}$ Potential technical limitations that could affect accuracy of perfusion measurement include low penetration of the light signal into deeper tissues, the requirement to place the probe directly on the tissue surface, possible dampening of signal by high bilirubin levels, and the presence of conditions that obstruct blood flow (eg, atherosclerosis). ${ }^{73}$

Pelletier et $\mathrm{al}^{78}$ conducted a cost analysis of NIRS tissue oximetry flap monitoring in patients undergoing autologous breast reconstruction. In this study, patients were admitted to either the intensive care unit $(n=25)$ or surgical floor $(n=25)$ after surgery; all patients received continuous monitoring using NIRS tissue oximetry. Overall, four patients experienced flap-related vascular complications; all were detected by NIRS oximetry. Patients monitored on the surgical floor had a mean cost reduction of $\$ 1,937$ compared with those monitored in the intensive care unit. The investigators concluded that NIRS tissue oximetry is an effective monitoring tool after breast reconstruction and can eliminate the need for specialized nursing care.

\section{Orthogonal polarization spectral imaging}

Another spectroscopic strategy for tissue perfusion assessment uses orthogonal, polarized light reflected off the tissue being studied, allowing for three-dimensional, realtime, continuous imaging of light-absorbing hemoglobin species within blood vessels and capillaries. Orthogonal polarization spectral (OPS) technology does not use dyes and the device is small, portable, and hand-held. ${ }^{69,72,79} \mathrm{It}$ has been investigated in imaging of both superficial tissues and numerous organs in humans and for intraoperative skin-flap assessment in animals. ${ }^{69,72,79,80}$ Intraoperative use of OPS imaging has been studied for measurement of microvascular perfusion in patients undergoing coronary artery bypass graft surgery who were assigned to minimal extracorporeal circulation or conventional extracorporeal circulation during the surgical procedure ${ }^{80}$ Potential limitations to its use are that the imaging probe must be placed directly on the tissue surface, ${ }^{69,72}$ that imaging high-velocity blood flow (eg, arterial vessels) depends on secondary image analysis, ${ }^{69}$ and that signal penetration depth is limited to $3 \mathrm{~mm}$ (must be inserted into the body to image deeply embedded tissues). ${ }^{79}$

\section{Indocyanine green imaging}

Indocyanine green (ICG) is an iodinated contrast dye that can be visualized under infrared or near-infrared light; it has been used extensively in intraoperative investigations of flap perfusion. ${ }^{81}$ Compared with fluorescein, ICG has a much higher molecular weight (775 versus 376 ) and, once injected, is much more highly bound to serum lipoproteins. ${ }^{63}$ These features allow the dye to remain inside vessels ${ }^{82}$ and in turn yield a more accurate assessment of blood flow dynamics. ICG is comparatively safer than sodium fluorescein for use in more rapid or repeated intraoperative assessments of tissue perfusion because it has a short plasma half-life (3-5 minutes), undergoes a high degree of hepatic clearance without modification, and has no known metabolites. ${ }^{63,82-84}$ The use of near-infrared wavelengths of light with ICG yields better translucence than sodium fluorescein. ${ }^{84}$ Use of ICG nevertheless may be limited by the need for a nearinfrared reading device to visualize results. ${ }^{84}$ Serious adverse events are rare, ${ }^{84,85}$ although ICG use is contraindicated in patients with known sensitivity to iodides or iodinated 
contrast agents; anaphylactic reactions can occur (two deaths have been reported after ICG injection during cardiac catheterization). ${ }^{86}$

\section{ICG-based intraoperative imaging technologies}

Given the advantages of ICG as a means for visualizing tissue perfusion, a number of ICG-based technologies have been developed.

\section{Photodynamic Eye ${ }^{\mathrm{TM}}$}

An near-infrared camera system that incorporates ICG fluorescence detection (Photodynamic Eye ${ }^{\mathrm{TM}}$; Hamamatsu Photonics, Hamamatsu City, Japan) when illuminated with a laser light-emitting diode has been investigated. The laser in this system emits light at wavelengths below the threshold for tissue damage. The camera is portable and maneuverable, and yields digitized, real-time images.$^{87} \mathrm{It}$ has been developed for indications such as visualization of sentinel lymph nodes/tumors in cancer patients ${ }^{88-90}$ and visualization of the sclerosant polidocanol during sclerotherapy in sclerotic veins. ${ }^{87}$ Piwkowski et al ${ }^{11}$ demonstrated the efficacy of this technology for assessment of intercostal muscle blood perfusion in a pilot study of patients undergoing pulmonary resection.

\section{IC-VIEW TM}

Similar to the Photodynamic Eye ${ }^{\mathrm{TM}}$, the IC-VIEWTM (Pulsion Medical Systems, AG, Munich, Germany) is a laser-fluorescence videography system that permits realtime visualization of ICG after intravenous injection. ${ }^{67}$ The IC-VIEW ${ }^{\mathrm{TM}}$ employs an infrared filter to detect fluorescence of ICG following an intravenous bolus of $0.5 \mathrm{mg} / \mathrm{kg} .{ }^{67,92}$ This device has been investigated for postoperative ICG assessment of tissue-flap perfusion in breast reconstruction, ${ }^{93}$ intraoperative assessment in aesthetic abdominoplasty, ${ }^{92}$ and free-flap transfer in several surgical models. ${ }^{67,94}$ IC-VIEW ${ }^{\text {TM }}$ has been used for intraoperative monitoring of perforator-flap perfusion during abdominoplasty ${ }^{92}$ as well as in acute and long-term postoperative follow-up in breast reconstruction. ${ }^{93} \mathrm{Holm}$ et al ${ }^{67}$ showed the accuracy of IC-VIEW ${ }^{\mathrm{TM}}$ for tissue monitoring across several different tissue types in several different reconstructive surgeries, and Mothes et al ${ }^{94}$ demonstrated that IC-VIEW ${ }^{\mathrm{TM}}$ tissue perfusion measurements predicted replantation failure more accurately than did clinical parameters such as surgeon ratings of tissue turgor, perfusion, bleeding, or temperature.
Fluorescence-Assisted Resection and Exploration system The Fluorescence-Assisted Resection and Exploration (FLARE ${ }^{\mathrm{TM}}$ ) system (owned by Beth Israel Deaconess Medical Center, Boston, MA, USA) is currently being developed for intraoperative assessment of tissue perfusion in breast reconstruction. ${ }^{95,96}$ FLARETM elaborates on existing laserfluorescence imaging systems by incorporating both a NIRS laser light-emitting diode and a white light-emitting diode that generate a signal over a $15-\mathrm{cm}$ diameter area. ${ }^{96}$ This dual system allows capture of color video of the surgical-site anatomy as well as tissue perfusion at the surgical site. The system can display these images merged or separately. ${ }^{96}$ Lee et $\mathrm{a}^{95}$ reported results from a dosing study using FLARE ${ }^{\mathrm{TM}}$ for visualization of deep inferior epigastric-flap perfusion at several time points during breast surgery in six patients after $2 \mathrm{mg}, 4 \mathrm{mg}$, or $6 \mathrm{mg}$ doses of ICG. The authors reported that in two of the six patients studied, the dominant perforator identified by FLARETM was not the perforator chosen by the surgeon during preoperative assessment using clinical judgment (ie, the surgeon chose an inferior vessel). ${ }^{95}$

\section{D-Light P}

The D-Light P (Karl Storz GmbH and Co, KG, Tuttlingen, Germany) is an ICG fluorescence-based NIRS laparoscope system that has been studied for intraoperative assessment of tissue perfusion in an experimental animal model by Diana et al. ${ }^{97}$ The authors showed the D-Light P system to accurately detect boundaries between ischemic and vascularized areas of mesenteric ischemia in swine. To our knowledge, no studies describing the use of D-Light $\mathrm{P}$ for perfusion assessment in humans have been published.

\section{SPY®/SPY Elite ${ }^{\circledR}$}

The SPY Elite ${ }^{\circledR}$ intraoperative perfusion assessment system (LifeCell Corporation, Branchburg, NJ, USA) is a widely used laser-ICG fluorescence imaging system currently indicated for intraoperative perfusion assessment in plastic, reconstructive, and gastrointestinal surgical procedures. ${ }^{82,86}$ Relative to the earlier SPY ${ }^{\circledR}$ intraoperative perfusion assessment system, SPY Elite ${ }^{\circledR}$ incorporates an updated laser with higher sensitivity and filtering power, allowing for fluorescence detection with lower ICG doses of $5 \mathrm{mg}-10 \mathrm{mg}$ per injection. ${ }^{56,86,98,99}$ Both SPY ${ }^{\circledR}$ and SPY Elite ${ }^{\circledR}$ generate quantitative perfusion values based on fluorescence intensity detected in the tissue. ${ }^{99-101}$ This system has been investigated for multiple intraoperative uses during breast reconstruction, including perfusion assessment of mastectomy skin flaps, 
pedicle flaps, and free-tissue transfers, ${ }^{56,98,99,101-103}$ and in head and neck ${ }^{104}$ and abdominal wall reconstruction surgeries. ${ }^{100}$

The clinical utility of the SPY ${ }^{\circledR}$ system in breast surgery has been described by Newman and Samson, ${ }^{102}$ who reported that perfusion problems identified with SPY ${ }^{\circledR}$ in four of eight patients undergoing free-flap breast reconstruction led to interventions that prevented flap necrosis in three patients. The fourth patient had no intervention and subsequently required reoperative flap salvage due to venous congestion. ${ }^{102}$ Similarly, Komorowska-Timek and Gurtner ${ }^{56}$ reported a reduction in postoperative complications after breast reconstruction from a historical value of $15.1 \%$ in more than 200 patients to $4 \%$ in 24 cases using SPY ${ }^{\circledR}$. Another study by Newman et $\mathrm{al}^{105}$ showed SPY ${ }^{\circledR}$ imaging to have $100 \%$ sensitivity and $91 \%$ specificity for intraoperative prediction of wound complications in women undergoing skin-sparing mastectomy. Phillips et $\mathrm{al}^{99}$ found that $\mathrm{SPY}{ }^{\circledR}$ predicted flap necrosis in 19 of 21 patients undergoing breast reconstruction, yielding a sensitivity level of $90 \%$. Phillips et a ${ }^{99}$ further observed that assessment using SPY ${ }^{\circledR}$ technology was nearly three times more accurate than fluorescein dye angiography in predicting skin-flap necrosis in patients undergoing breast reconstruction. More recently, Sood and Glat ${ }^{103}$ conducted a retrospective study in 91 cancer patients undergoing breast reconstruction with and without use of SPY ${ }^{\circledR}$ technology. Of the 39 patients who were assessed both by clinical assessment and via SPY ${ }^{\circledR}$, the rate of identification of mastectomy-flap ischemia was 3\% via clinical assessment versus $51 \%$ with $\operatorname{SPY}^{\circledR}(P<0.0001)$.

Regarding the use of SPY ${ }^{\circledR}$ imaging in other surgical settings, Pestana et al $^{71}$ evaluated flap perfusion during different types of surgery involving free-flap transfer; in several cases, intraoperative debridement of areas with poor perfusion identified by SPY ${ }^{\circledR}$ imaging was considered by the authors to have prevented postoperative wound healing complications. Patel et al ${ }^{100}$ recently reported results from a retrospective evaluation of SPY ${ }^{\circledR}$ technology in complex abdominal wall reconstruction. In this study, wound-healing-related complications occurred in five of 12 patients $(42 \%)$ who underwent surgery without use of SPY ${ }^{\circledR}$ versus one of five (20\%) with SPY ${ }^{\circledR}$. SPY ${ }^{\circledR}$ technology has also been shown to be useful for aiding flap perfusion assessment in patients undergoing head and neck surgery. ${ }^{104,106}$

Chatterjee et al ${ }^{107}$ conducted a cost-effectiveness analysis of laser-assisted ICG angiography with SPY ${ }^{\circledR}$ technology in immediate breast reconstruction patients who underwent mastectomy followed by autologous free-flap surgery at a single institution. In this study, the mean incremental cost-utility ratio (representing the added cost to prolong a patient's life by 1 year of perfect health) was calculated for patient groups who underwent laser-assisted ICG angiography versus those who did not. Cost-utility ratios were calculated on the basis of cost of surgical procedure (per-procedure price for use of laserassisted ICG angiography was set at \$1,295 in 2011 dollars), probability of postsurgical complications, and expected quality-adjusted life years. According to the investigators' review of published literature, overall complication rates were $26.5 \%$ without laser-assisted ICG angiography versus $5 \%$ with ICG angiography. Use of ICG angiography was considered cost-effective if the cost-utility ratio was between $\$ 0$ and $\$ 50,000$ per quality-adjusted life year. The analysis revealed an incremental cost-utility ratio of $\$ 3,517$ (cost per quality-adjusted life year gained); use of laser-assisted ICG angiography was cost-effective when the complication rate without ICG angiography was $4 \%$ or more.

\section{Discussion: future applications of emerging tissue perfusion technologies}

Reconstructive surgeries, including complex ventral hernia repair, are often marked by postoperative wound-healing complications related to poor tissue perfusion. Older technologies that allow for quantitative assessment of tissue perfusion pose significant limitations and are not widely used. Currently, most surgeons rely upon clinical judgment, gauging tissue viability on the basis of subjective assessments of tissue turgor, perfusion, temperature, and bleeding.

In order to improve postoperative recovery for patients undergoing reconstructive surgery, novel methods for intraoperative assessment of tissue perfusion (eg, spectroscopic and ICG imaging) have been successfully developed in recent years. Spectroscopic imaging technologies, such as NIRS and OPS, appear promising but continue to pose important challenges, including a limited depth of tissue visualization that may limit usefulness in certain clinical situations. Nevertheless, the hand-held portability and high-quality imaging of OPS technology and its ease of use may further its application, particularly in situations where injection of contrast dye is contraindicated. ICG-based laser-fluorescence imaging systems have enjoyed relatively greater clinical investigation than OPS for reconstructive procedures. The desirable chemical and pharmacokinetic properties of ICG, combined with the emergence of technology that maximizes the potential for high-quality, real-time imaging, such as SPY Elite $^{\circledR}$, make it an intriguing option that overcomes many of the limitations of older imaging methods. SPY ${ }^{\circledR}$ technology has 
already been used successfully in multiple surgical settings, including head and neck surgery, ${ }^{71}$ breast surgery, ${ }^{56,98,99,102,105}$ lower extremity reconstruction, ${ }^{71}$ organ transplant, ${ }^{82}$ and coronary artery bypass graft procedures. ${ }^{82}$

It is likely that the greatest benefits associated with these novel technologies will be rooted in their potential to finally provide clinicians with highly accurate, real-time information regarding the precise location of poorly perfused tissue during surgery. From this perspective, intraoperative quantitative perfusion assessment presents the surgeon with an opportunity to optimize perfusion at the time of herniorrhaphy, rather than waiting for clinical signs of poor perfusion or related complications to emerge postoperatively. It is now possible for surgeons to intraoperatively and proactively debride tissue as needed, regardless of whether the surgical wound is closed or left open at the end of surgery and without having to wait for signs of necrosis to appear before taking action. Early evidence from published clinical reports supports the use of such technologies and describes cases in which these technologies have been successfully used to intraoperatively optimize tissue perfusion and potentially avoid perfusion-related wound-healing complications such as flap necrosis. ${ }^{71,95}$ Because such complications are associated with postoperative debridement, secondary revisional surgery, lengthened hospital stay, and complex recovery, the potential clinical and economic benefits of these technologies for patients and health systems should not be underestimated.

On the basis of their utility for real-time assessment of tissue-flap viability in other types of reconstructive procedures, it is reasonable to propose that these novel technologies will also have good use in abdominal wall reconstruction procedures such as ventral hernia repair, where accurate assessment of tissue viability is just as critical as in other settings. Although both OPS and ICG-based tissue perfusion technologies appear promising, further study is needed in high-quality clinical trials. Their usefulness as a means to help surgeons prevent avoidable postsurgical complications will be solidified with further study and clinical exposure across various types of reconstructive surgeries.

\section{Acknowledgments}

The author gratefully acknowledges the input of Evan S. Garfein, MD, on this manuscript. Editorial support for this article was provided by Peloton Advantage, LLC, Parsippany, NJ, USA and was funded by LifeCell Corporation, Branchburg, NJ, USA. The opinions expressed in this article are those of the author. The author received no honoraria, fee for service, or other form of financial support related to the development of this article.

\section{Disclosure}

The author reports no conflict of interest in this work.

\section{References}

1. Rohrich RJ, Lowe JB, Hackney FL, Bowman JL, Hobar PC. An algorithm for abdominal wall reconstruction. Plast Reconstr Surg. 2000;105(1):202-216; quiz 217.

2. Christison-Lagay ER, Kelleher CM, Langer JC. Neonatal abdominal wall defects. Semin Fetal Neonatal Med. 2011;16(3):164-172.

3. Mudge M, Hughes LE. Incisional hernia: a 10 year prospective study of incidence and attitudes. Br J Surg. 1985;72(1):70-71.

4. Israelsson LA, Jonsson T. Incisional hernia after midline laparotomy: a prospective study. Eur J Surg. 1996;162(2):125-129.

5. Sugerman HJ, Kellum JM, Reines HD, DeMaria EJ, Newsome HH, Lowry JW. Greater risk of incisional hernia with morbidly obese than steroid-dependent patients and low recurrence with prefascial polypropylene mesh. Am J Surg. 1996;171(1):80-84.

6. Hodgson NC, Malthaner RA, Ostbye T. The search for an ideal method of abdominal fascial closure: a meta-analysis. Ann Surg. 2000;231(3): 436-442.

7. Breuing K, Butler CE, Ferzoco S, et al; Ventral Hernia Working Group. Incisional ventral hernias: review of the literature and recommendations regarding the grading and technique of repair. Surgery. 2010;148(3): 544-558.

8. DiCocco JM, Magnotti LJ, Emmett KP, et al. Long-term follow-up of abdominal wall reconstruction after planned ventral hernia: a 15-year experience. J Am Coll Surg. 2010;210(5):686-695, 695-698.

9. de Vries Reilingh TS, Bodegom ME, van Goor H, Hartman EH, van der Wilt GJ, Bleichrodt RP. Autologous tissue repair of large abdominal wall defects. Br J Surg. 2007;94(7):791-803.

10. Schmitz C, Schramm S, Hankiss J. Reconstruction of a four-quadrant full-thickness abdominal wall defect after removal and debridement of an infected mesh hernioplasty. J Plast Reconstr Aesthet Surg. 2011;64(2):e44-e46.

11. Ko JH, Wang EC, Salvay DM, Paul BC, Dumanian GA. Abdominal wall reconstruction: lessons learned from 200 "components separation" procedures. Arch Surg. 2009;144(11):1047-1055.

12. Ramirez OM, Ruas E, Dellon AL. "Components separation" method for closure of abdominal-wall defects: an anatomic and clinical study. Plast Reconstr Surg. 1990;86(3):519-526.

13. Park AE, Roth JS, Kavic SM. Abdominal wall hernia. Curr Probl Surg. 2006;43(5):326-375.

14. Voyles CR, Richardson JD, Bland KI, Tobin GR, Flint LM, Polk HC. Emergency abdominal wall reconstruction with polypropylene mesh: short-term benefits versus long-term complications. Ann Surg. 1981;194(2):219-223.

15. Kapischke M, Schulz T, Schipper T, Tensfeldt J, Caliebe A. Open versus laparoscopic incisional hernia repair: something different from a meta-analysis. Surg Endosc. 2008;22(10):2251-2260.

16. Kingsnorth A, Banerjea A, Bhargava A. Incisional hernia repair laparoscopic or open surgery? Ann R Coll Surg Engl. 2009;91(8): 631-636.

17. Olmi S, Scaini A, Cesana GC, Erba L, Croce E. Laparoscopic versus open incisional hernia repair: an open randomized controlled study. Surg Endosc. 2007;21(4):555-559.

18. de Vries Reilingh TS, van Goor H, Rosman C, et al. "Components separation technique" for the repair of large abdominal wall hernias. J Am Coll Surg. 2003;196(1):32-37.

19. de Vries Reilingh TS, van Goor H, Charbon JA, et al. Repair of giant midline abdominal wall hernias: "components separation technique" versus prosthetic repair: interim analysis of a randomized controlled trial. World J Surg. 2007;31(4):756-763. 
20. Silverman RP, Singh NK, Li EN, et al. Restoring abdominal wall integrity in contaminated tissue-deficient wounds using autologous fascia grafts. Plast Reconstr Surg. 2004;113(2):673-675.

21. Wang HD, Singh DP. The use of indocyanine green angiography to prevent wound complications in ventral hernia repair with open components separation technique. Hernia. 2013;17(3):397-402.

22. Gonzalez R, Rehnke RD, Ramaswamy A, Smith CD, Clarke JM, Ramshaw BJ. Components separation technique and laparoscopic approach: a review of two evolving strategies for ventral hernia repair. Am Surg. 2005;71(7):598-605.

23. Leber GE, Garb JL, Alexander AI, Reed WP. Long-term complications associated with prosthetic repair of incisional hernias. Arch Surg. 1998;133(4):378-382.

24. Paul A, Korenkov M, Peters S, Köhler L, Fischer S, Troidl H. Unacceptable results of the Mayo procedure for repair of abdominal incisional hernias. Eur J Surg. 1998;164(5):361-367.

25. Anthony T, Bergen PC, Kim LT, et al. Factors affecting recurrence following incisional herniorrhaphy. World J Surg. 2000;24(1):95-100; discussion 101.

26. Read RC, Yoder G. Recent trends in the management of incisional herniation. Arch Surg. 1989;124(4):485-488.

27. DeNoto G 3rd, Reaven N, Funk S. Ventral hernia: retrospective cost analysis of primary repair, repair with synthetic mesh, and repair with acellular xenograft implant. Open Access Surgery. 2013;6:23-32.

28. Luijendijk RW, Hop WC, van den Tol MP, et al. A comparison of suture repair with mesh repair for incisional hernia. $N$ Engl $J$ Med. 2000;343(6):392-398.

29. Cobb WS, Harris JB, Lokey JS, McGill ES, Klove KL. Incisional herniorrhaphy with intraperitoneal composite mesh: a report of 95 cases. Am Surg. 2003;69(9):784-787.

30. Bauer JJ, Harris MT, Kreel I, Gelernt IM. Twelve-year experience with expanded polytetrafluoroethylene in the repair of abdominal wall defects. Mt Sinai J Med. 1999;66(1):20-25.

31. Kurian A, Gallagher S, Cheeyandira A, Josloff R. Predictors of in-hospital length of stay after laparoscopic ventral hernia repair: results of multivariate logistic regression analysis. Surg Endosc. 2010;24(11):2789-2792.

32. McGreevy JM, Goodney PP, Birkmeyer CM, Finlayson SR, Laycock WS, Birkmeyer JD. A prospective study comparing the complication rates between laparoscopic and open ventral hernia repairs. Surg Endosc. 2003;17(11):1778-1780.

33. Perrone JM, Soper NJ, Eagon JC, et al. Perioperative outcomes and complications of laparoscopic ventral hernia repair. Surgery. 2005;138(4):708-715; discussion 715-716.

34. Rosen MJ. Polyester-based mesh for ventral hernia repair: is it safe? Am J Surg. 2009;197(3):353-359.

35. Martín-Duce A, Noguerales F, Villeta R, et al. Modifications to Rives technique for midline incisional hernia repair. Hernia. 2001;5(2): 70-72.

36. Houck JP, Rypins EB, Sarfeh IJ, Juler GL, Shimoda KJ. Repair of incisional hernia. Surg Gynecol Obstet. 1989;169(5):397-399.

37. Dunne JR, Malone DL, Tracy JK, Napolitano LM. Abdominal wall hernias: risk factors for infection and resource utilization. $J$ Surg Res. 2003;111(1):78-84.

38. Finan KR, Vick CC, Kiefe CI, Neumayer L, Hawn MT. Predictors of wound infection in ventral hernia repair. Am J Surg. 2005;190(5): 676-681.

39. Malik AM, Jawaid A, Talpur AH, Laghari AA, Khan A. Mesh versus non-mesh repair of ventral abdominal hernias. J Ayub Med Coll Abbottabad. 2008;20(3):54-56.

40. White TJ, Santos MC, Thompson JS. Factors affecting wound complications in repair of ventral hernias. Am Surg. 1998;64(3): 276-280.

41. Awad ZT, Puri V, LeBlanc K, et al. Mechanisms of ventral hernia recurrence after mesh repair and a new proposed classification. $J \mathrm{Am}$ Coll Surg. 2005;201(1):132-140.
42. van’t Riet M, de Vos van Steenwijk PJ, Bonjer HJ, Steyerberg EW, Jeekel J. Mesh repair for postoperative wound dehiscence in the presence of infection: is absorbable mesh safer than non-absorbable mesh? Hernia. 2007;11(5):409-413.

43. Hawn MT, Gray SH, Snyder CW, Graham LA, Finan KR, Vick CC. Predictors of mesh explantation after incisional hernia repair. Am J Surg. 2011;202(1):28-33.

44. Heniford BT, Park A, Ramshaw BJ, Voeller G. Laparoscopic repair of ventral hernias: nine years' experience with 850 consecutive hernias. Ann Surg. 2003;238(3):391-399; discussion 399-400.

45. Diaz JJ, Conquest AM, Ferzoco SJ, et al. Multi-institutional experience using human acellular dermal matrix for ventral hernia repair in a compromised surgical field. Arch Surg. 2009;144(3):209-215.

46. Bencini L, Sanchez LJ, Boffi B, et al. Comparison of laparoscopic and open repair for primary ventral hernias. Surg Laparosc Endosc Percutan Tech. 2009;19(4):341-344.

47. Birch DW. Characterizing laparoscopic incisional hernia repair. Can J Surg. 2007;50(3):195-201.

48. Satterwhite TS, Miri S, Chung C, Spain D, Lorenz HP, Lee GK. Outcomes of complex abdominal herniorrhaphy: experience with 106 cases. Ann Plast Surg. 2012;68(4):382-388.

49. Satterwhite TS, Miri S, Chung C, Spain DA, Lorenz HP, Lee GK. Abdominal wall reconstruction with dual layer cross-linked porcine dermal xenograft: the "Pork Sandwich" herniorraphy. J Plast Reconstr Aesthet Surg. 2012;65(3):333-341.

50. Clarke JM. Incisional hernia repair by fascial component separation: results in 128 cases and evolution of technique. Am J Surg. 2010;200(1): 2-8.

51. Helton WS, Fisichella PM, Berger R, Horgan S, Espat NJ, Abcarian H. Short-term outcomes with small intestinal submucosa for ventral abdominal hernia. Arch Surg. 2005;140(6):549-560; discussion $560-562$.

52. Mangram AJ, Horan TC, Pearson ML, Silver LC, Jarvis WR. Guideline for prevention of surgical site infection, 1999. Hospital Infection Control Practices Advisory Committee. Infect Control Hosp Epidemiol. 1999;20(4):250-278; quiz 279-280.

53. Futran ND, Stack BC, Hollenbeak C, Scharf JE. Green light photoplethysmography monitoring of free flaps. Arch Otolaryngol Head Neck Surg. 2000;126(5):659-662.

54. Loos MS, Freeman BG, Lorenzetti A. Zone of injury: a critical review of the literature. Ann Plast Surg. 2010;65(6):573-577.

55. Garvey PB, Salavati S, Feng L, Butler CE. Perfusion-related complications are similar for DIEP and muscle-sparing free TRAM flaps harvested on medial or lateral deep inferior epigastric artery branch perforators for breast reconstruction. Plast Reconstr Surg. 2011;128(6): $581 \mathrm{e}-589 \mathrm{e}$

56. Komorowska-Timek E, Gurtner GC. Intraoperative perfusion mapping with laser-assisted indocyanine green imaging can predict and prevent complications in immediate breast reconstruction. Plast Reconstr Surg. 2010;125(4):1065-1073.

57. Jaccard Y, Walther $\mathrm{S}$, Anderson $\mathrm{S}$, et al. Influence of secondary infection on amputation in chronic critical limb ischemia. Eur J Vasc Endovasc Surg. 2007;33(5):605-609.

58. de Weerd L, Mercer JB, Weum S. Dynamic infrared thermography. Clin Plast Surg. 2011;38(2):277-292.

59. Seifalian AM, Stansby G, Jackson A, Howell K, Hamilton G. Comparison of laser Doppler perfusion imaging, laser Doppler flowmetry, and thermographic imaging for assessment of blood flow in human skin. Eur J Vasc Surg. 1994;8(1):65-69.

60. Eichhorn W, Auer T, Voy ED, Hoffmann K. Laser Doppler imaging of axial and random pattern flaps in the maxillo-facial area. A preliminary report. J Craniomaxillofac Surg. 1994;22(5):301-306.

61. Arsenault KA, Al-Otaibi A, Devereaux PJ, Thorlund K, Tittley JG, Whitlock RP. The use of transcutaneous oximetry to predict healing complications of lower limb amputations: a systematic review and meta-analysis. Eur J Vasc Endovasc Surg. 2012;43(3):329-336. 
62. Fife CE, Smart DR, Sheffield PJ, Hopf HW, Hawkins G, Clarke D. Transcutaneous oximetry in clinical practice: consensus statements from an expert panel based on evidence. Undersea Hyperb Med. 2009;36(1):43-53.

63. Eren S, Rübben A, Krein R, Larkin G, Hettich R. Assessment of microcirculation of an axial skin flap using indocyanine green fluorescence angiography. Plast Reconstr Surg. 1995;96(7):1636-1649.

64. Losken A, Styblo TM, Schaefer TG, Carlson GW. The use of fluorescein dye as a predictor of mastectomy skin flap viability following autologous tissue reconstruction. Ann Plast Surg. 2008;61(1):24-29.

65. Ffytche TJ, Shilling JS, Chisholm IH, Federman JL. Indications for fluorescein angiography in disease of the ocular fundus: a review. $J R$ Soc Med. 1980;73(5):362-365.

66. Matsui A, Lee BT, Winer JH, Laurence RG, Frangioni JV. Quantitative assessment of perfusion and vascular compromise in perforator flaps using a near-infrared fluorescence-guided imaging system. Plast Reconstr Surg. 2009;124(2):451-460.

67. Holm C, Tegeler J, Mayr M, Becker A, Pfeiffer UJ, Mühlbauer W. Monitoring free flaps using laser-induced fluorescence of indocyanine green: a preliminary experience. Microsurgery. 2002;22(7):278-287.

68. Chang EI, Ly DP, Wey PD. Comparison of aesthetic breast reconstruction after skin-sparing or conventional mastectomy in patients receiving preoperative radiation therapy. Ann Plast Surg. 2007;59(1):78-81.

69. Cerný V, Turek Z, Parízková R. Orthogonal polarization spectral imaging. Physiol Res. 2007;56(2):141-147.

70. Rival R, Bance M, Antonyshyn O, Phillips J, Pang CY. Comparison of laser Doppler flowmeter and radioactive microspheres in measuring blood flow in pig skin flaps. Laryngoscope. 1995;105(4 Pt 1): 383-386

71. Pestana IA, Coan B, Erdmann D, Marcus J, Levin LS, Zenn MR. Early experience with fluorescent angiography in free-tissue transfer reconstruction. Plast Reconstr Surg. 2009;123(4):1239-1244.

72. Olivier WA, Hazen A, Levine JP, Soltanian H, Chung S, Gurtner GC. Reliable assessment of skin flap viability using orthogonal polarization imaging. Plast Reconstr Surg. 2003;112(2):547-555.

73. Lipcsey M, Woinarski NC, Bellomo R. Near infrared spectroscopy (NIRS) of the thenar eminence in anesthesia and intensive care. Ann Intensive Care. 2012;2(1):11.

74. Gravvanis AI, Tsoutsos DA, Karakitsos D, et al. Application of the pedicled anterolateral thigh flap to defects from the pelvis to the knee. Microsurgery. 2006;26(6):432-438.

75. Sako H, Hadama T, Miyamoto S, et al. Effect of prostaglandin E1 on ischemia-reperfusion injury during abdominal aortic aneurysm surgery. Surg Today. 2006;36(2):140-146.

76. Schoen J, Husemann L, Tiemeyer C, et al. Cognitive function after sevoflurane- vs propofol-based anaesthesia for on-pump cardiac surgery: a randomized controlled trial. Br J Anaesth. 2011;106(6):840-850.

77. Hirano Y, Omura K, Tatsuzawa Y, Shimizu J, Kawaura Y, Watanabe G Tissue oxygen saturation during colorectal surgery measured by nearinfrared spectroscopy: pilot study to predict anastomotic complications. World J Surg. 2006;30(3):457-461.

78. Pelletier A, Tseng C, Agarwal S, Park J, Song D. Cost analysis of near-infrared spectroscopy tissue oximetry for monitoring autologous free tissue breast reconstruction. J Reconstr Microsurg. 2011;27(8): 487-494.

79. Lupi O, Semenovitch I, Treu C, Bouskela E. Orthogonal polarization technique in the assessment of human skin microcirculation. Int $J$ Dermatol. 2008;47(5):425-431.

80. Donndorf P, Kühn F, Vollmar B, et al. Comparing microvascular alterations during minimal extracorporeal circulation and conventional cardiopulmonary bypass in coronary artery bypass graft surgery: a prospective, randomized study. J Thorac Cardiovasc Surg. 2012;144(3): 677-683.

81. Liu DZ, Mathes DW, Zenn MR, Neligan PC. The application of indocyanine green fluorescence angiography in plastic surgery. $J$ Reconstr Microsurg. 2011;27(6):355-364.
82. Zenn MR. Fluorescent angiography. Clin Plast Surg. 2011;38(2): 293-300.

83. Jones GE, Harper JR. Technologic advances in breast surgery. In: Jones GE, editor. Bostwick's Plastic and Reconstructive Breast Surgery. 3rd ed. St Louis, MO: CRC Press; 2010:235.

84. Alander JT, Kaartinen I, Laakso A, et al. A review of indocyanine green fluorescent imaging in surgery. Int J Biomed Imaging. 2012;2012: 940585.

85. Polom K, Murawa D, Rho YS, Nowaczyk P, Hünerbein M, Murawa P. Current trends and emerging future of indocyanine green usage in surgery and oncology: a literature review. Cancer. 2011;117(21): 4812-4822.

86. SPY Elite Pack and SPY Elite Kit [Instructions for Use]. Branchburg, NJ: LifeCell Corporation; 2011.

87. Kikuchi M, Hosokawa K. Visualized sclerotherapy of varicose veins Dermatol Surg. 2010;36 Suppl 2:1050-1055.

88. Ishizuka M, Nagata H, Takagi K, Iwasaki Y, Kubota K. Fluorescence imaging visualizes three sets of regional lymph nodes in patients with lower rectal cancer. Hepatogastroenterology. 2012;59(117): 1381-1384.

89. Ishizuka M, Kubota K, Kita J, Shimoda M, Kato M, Sawada T. Intraoperative observation using a fluorescence imaging instrument during hepatic resection for liver metastasis from colorectal cancer. Hepatogastroenterology. 2012;59(113):90-92.

90. Peloso A, Franchi E, Canepa MC, et al. Combined use of intraoperative ultrasound and indocyanine green fluorescence imaging to detect liver metastases from colorectal cancer. HPB (Oxford). 2013;15(12): 928-934.

91. Piwkowski C, Gabryel P, Gąsiorowskia Ł, et al. Indocyanine green fluorescence in the assessment of the quality of the pedicled intercostal muscle flap: a pilot study. Eur J Cardiothorac Surg. 2013;44(1):e77-e81.

92. Mayr M, Holm C, Höfter E, Becker A, Pfeiffer U, Mühlbauer W. Effects of aesthetic abdominoplasty on abdominal wall perfusion: a quantitative evaluation. Plast Reconstr Surg. 2004;114(6):1586-1594.

93. Heitland AS, Markowicz MP, Koellensperger E, Schoth F, Pallua N. Early and long-term evaluation of perfusion changes in free DIEP-flaps for breast reconstruction via IC-view and duplex ultrasound: autonomous or peripheral perfusion? J Reconstr Microsurg. 2009;25(2): $139-145$

94. Mothes H, Dönicke T, Friedel R, Simon M, Markgraf E, Bach O. Indocyanine-green fluorescence video angiography used clinically to evaluate tissue perfusion in microsurgery. J Trauma. 2004;57(5): $1018-1024$.

95. Lee BT, Hutteman M, Gioux S, et al. The FLARE intraoperative near-infrared fluorescence imaging system: a first-in-human clinical trial in perforator flap breast reconstruction. Plast Reconstr Surg. 2010;126(5):1472-1481

96. Lee BT, Matsui A, Hutteman M, et al. Intraoperative near-infrared fluorescence imaging in perforator flap reconstruction: current research and early clinical experience. $J$ Reconstr Microsurg. 2010;26(1): 59-65.

97. Diana M, Noll E, Diemunsch P, et al. Enhanced-reality video fluorescence: a real-time assessment of intestinal viability. Ann Surg. Epub March 25, 2013.

98. Mohebali J, Gottlieb LJ, Agarwal JP. Further validation for use of the retrograde limb of the internal mammary vein in deep inferior epigastric perforator flap breast reconstruction using laser-assisted indocyanine green angiography. J Reconstr Microsurg. 2010;26(2):131-135.

99. Phillips BT, Lanier ST, Conkling N, et al. Intraoperative perfusion techniques can accurately predict mastectomy skin flap necrosis in breast reconstruction: results of a prospective trial. Plast Reconstr Surg. 2012;129(5):778e-788e.

100. Patel KM, Bhanot P, Franklin B, Albino F, Nahabedian MY. Use of intraoperative indocyanin-green angiography to minimize wound healing complications in abdominal wall reconstruction. J Plast Surg Hand Surg. 2013;47(6):476-480. 
101. Newman MI, Jack MC, Samson MC. SPY-Q analysis toolkit values potentially predict mastectomy flap necrosis. Ann Plast Surg. 2013;70(5):595-598.

102. Newman MI, Samson MC. The application of laser-assisted indocyanine green fluorescent dye angiography in microsurgical breast reconstruction. J Reconstr Microsurg. 2009;25(1):21-26.

103. Sood M, Glat P. Potential of the SPY intraoperative perfusion assessment system to reduce ischemic complications in immediate postmastectomy breast reconstruction. Ann Surg Innov Res. 2013;7(1):9.

104. Green JM, Thomas S, Sabino J, et al. Use of intraoperative fluorescent angiography to assess and optimize free tissue transfer in head and neck reconstruction. J Oral Maxillofac Surg. 2013;71(8):1439-1449.
105. Newman MI, Samson MC, Tamburrino JF, Swartz KA. Intraoperative laser-assisted indocyanine green angiography for the evaluation of mastectomy flaps in immediate breast reconstruction. J Reconstr Microsurg. 2010;26(7):487-492.

106. Woodard CR, Most SP. Intraoperative angiography using laser-assisted indocyanine green imaging to map perfusion of forehead flaps. Arch Facial Plast Surg. 2012;14(4):263-269.

107. Chatterjee A, Krishnan NM, Van Vliet MM, Powell SG, Rosen JM, Ridgway EB. A comparison of free autologous breast reconstruction with and without the use of laser-assisted indocyanine green angiography: a cost-effectiveness analysis. Plast Reconstr Surg. 2013;131(5):693e-701e.
Open Access Surgery

\section{Publish your work in this journal}

Open Access Surgery is an international, peer-reviewed, open access journal that focuses on all aspects of surgical procedures and interventions. Patient care around the peri-operative period and patient outcomes post surgery are key topics. All grades of surgery from minor cosmetic interventions to major surgical procedures are covered. Novel techniques

Submit your manuscript here: http://www.dovepress.com/open-access-surgery-journal

\section{Dovepress}

and the utilization of new instruments and materials, including implants and prostheses that optimize outcomes constitute major areas of interest. The manuscript management system is completely online and includes a very quick and fair peer-review system. Visit http://www.dovepress.com/ testimonials.php to read real quotes from published authors. 